\title{
PATHOPSYCHOLOGICAL GENDER FEATURES OF THE ADAPTATION AND MOTIVATION PROCESSES AMONG STUDENTS OF HIGHER EDUCATION- AL MEDICAL INSTITUTIONS OF THE FIRST SEMESTER OF TRAINING
}

\author{
Ponomarev V., Vovk V., Sukachova O., Mishchenko A., Suvorova-Grigorovich A.
}

\section{Ponomarev Vladimir I. ${ }^{1}$ Пономарьов Володимир Іванович ${ }^{2}$ \\ Vovk Viktoriуа ${ }^{1}$ / Вовк Вікторія Ігорівна \\ Sukachova Olga ${ }^{1} /$ Сукачова Ольга Миколаївна² \\ Mishchenko Alexander ${ }^{1} /$ Міщенко Олександр \\ Миколайович ${ }^{2}$ \\ Suvorova-Grigorovich Anna $1 /$ \\ Суворова-Григорович Ганна Олександрівна ${ }^{2}$}

'V.N. Karazin Kharkiv National University; Freedom Square 4, Kharkiv, 61022, Ukraine

${ }^{2}$ Харківський національний університет імені В. Н. Каразіна; майдан Свободи 4, м. Харків, 61022, Україна

\author{
e-mail:v.i.ponomaryov@ukr.net; ORCID 0000-0003-2513-3187 \\ e-mail: v.i.vovk@ukr.net; ORCID 0000-0002-9547-8968 \\ e-mail: olga_sukachova@ukr.net; ORCID 0000-0003-0742-3041 \\ e-mail: alex_mischenko1976@ukr.net; ORCID 0000-0003-0043-2252 \\ e-mail: grigorovichaa@ukr.net; ORCID 000-0002-9843-9286
}

ПАТОПСИХОЛОГИЧЕСКИЕ ГЕНДЕРНЫЕ ОСОБЕННОСТИ ПРОЦЕССОВ АДАПТАЦИИ И МОТИВАЦИИ К УЧЕБНОЙ ДЕЯТЕЛЬНОСТИ У СТУДЕНТОВ ВЫСШИХ УЧЕБНЫХ МЕДИЦИНСКИХ ЗАВЕДЕНИИ ПЕРВОГО СЕМЕСТРА ОБУЧЕНИЯ

Аннотация. $\quad$ Приведен анализ особенностей адаптационного периода студентов-первокурсников медицинского вуза, а также мотивации как биохимического и физиологического процессов организма. Указано, что мотивация не является статичным понятием и подвергается трансформации, а деятельность организма определяется доминирующей мотивацией, которая подчиняет себе все другие. Обследованы адаптационные и мотивационные гендерные особенности у 67 студентов медицинского факультета первого курса обучения. Полученные данные свидетельствуют о преимущественно внешней мотивированности у студентов-парней и внутренней мотивированности у студентов-девушек. У девушек мотивами выбора были познавательные мотивы и мотивы профессиональных достижений, в то время как у парней - социальные мотивы и мотивы личного престижа. Выявленные особенности мотивации являются наиболее значимыми для успеваемости в учебе. Также был выявлен ярко выраженный психастенический синдром (особенно у девушек), что подтверждает учебу на первом курсе вуза как стрессогенный и дезадаптивный фактор. Полученные данные нуждаются в дальнейшем углубленном исследовании.

Ключевые слова: астения, дезадаптация, стресс, мотивация, студенты-медики, гендер, обучение, ВУз.

PATHOPSYCHOLOGICAL GENDER FEATURES OF THE ADAPTATION AND MOTIVATION PROCESSES AMONG STUDENTS OF HIGHER EDUCATIONAL MEDICAL INSTITUTIONS OF THE FIRST SEMESTER OF TRAINING

Summary: $\quad$ The analysis of the peculiarities of the adaptation period of the first-year students of the medical school is given, as well as motivation as a biochemical and physiological processes of the organism. It is indicated that motivation is not a static concept and is subject to transformation, and the activity of the organism is determined by the dominant motivation, which subordinates all others. Adaptational and motivational gender features were studied among 67 first year students of the medical school. The obtained data testify to the predominantly external motivation of male students and internal motivation among female students. The motives of choice for girls were the cognitive motives and motives of professional achievements, while the guys had social motives and motives for personal prestige. Identified features of motivation are the most significant for academic achievement. Also, a pronounced psychoasthenic syndrome (especially among girls) was revealed, that confirms the study in the first year of the university as a stressful and disadaptive factor. The obtained data is required further in-depth study.

Key words: $\quad$ asthenia, disadaptation, stress, motivation, medical students, gender, training, university. 
Relevance. Applying for education in higher education institutions, yesterday's schoolchildren are exposed to stress. Stressors compose a lot of factors - from usual way of life changing (school, parent-family, etc.) to a significantly increased volume and complexity of the information studied. It is known that students of medical universities are classified as a risk group for the syndrome of emotional burnout, which is caused both by the enumerated environmental and personal factors, which include personal deviations, a high level of anxiety, neuroticism, etc. [1, 4]. At the same time, the way in which the period of adaptation to the new conditions of life of firstyear medical students will pass, is important not only for the formation of motivation for learning, but also for the emergence of the personality of the future doctor, thereby indirectly determining his future successful professional activity [6]. Of course, the power of motivation, the desire to obtain knowledge for students of medical schools is important as for any other educational institutions. The health of the nation, a physically and psychologically healthy society is what we all aspire to and what is not possible without the participation of competent medical specialists.

Understanding this and using internal adequate motivational resources will enable students to intensify their own adaptive capabilities and resist inevitable stressful situations [3, 8]. Motivation literally means «what causes movement» [2]. During any motivation, activation of the motor system is observed, although different forms of motivation are realized in different patterns of motor excitation. Educational motivation along with other types of motivation is characterized by focus, systemic, sustainable and dynamic. All types of motivation are characterized by an increase of the tone of the sympathetic system, expressed in vegetative reactions. The second phase of motivation is an increase of search activity, which is purposeful ; the actualization of memory is a necessary link for the implementation of targeted behavior, primarily the formation of goals and possible ways to achieve them. An indispensable manifestation of motivation is the genesis of subjective emotional experiences.

Negative emotional tone is the most typical form of subjective reflection of motivation [2]. At the same time, there is another class of subjective experiences with a positive sign that characterizes the group of motivations that we study in this work: the behavior of curiosity, the desire for creative activity, learning, etc. The motivational sphere is not a static concept and is the subject to transformation. It is known that at any given time the organism's activity is determined by the motivation that is dominant in terms of survival and adaptation. After the completion of one motivated behavior, the organism is dominated by the following motivation, motivated by social and biological significance. Leading motivation subordinates all others $[2,5]$.

On the basis of the foregoing, it seems to us high importance to study the motivational sphere and adaptability of the first-year medical students.

Purpose of the study. The study of adaptive and motivational characteristics of the first year students of medical universities.

Materials and methods. 67 first year students of the medical school took part in the study, 42 of them were girls and 25 were boys from the age of 16 to 23 .

When studying the adaptation process, the «Multi-level personal questionnaire "Adaptivity»» was used, and for studying motives - the method "Studying the motives of student learning activities» was used.

A multi-level personal questionnaire (MPQ) «Adaptivity» was developed by A.G. Maklakov and S.V. Chermyanin (1993). It is designed to study the adaptive capacity of the individual on the basis of assessing some psychophysiological and socio-psychological characteristics that reflect the integral features of mental and social development. The questionnaire was adopted as a standardized method and recommended to be used for problems solving in professional psychological selection, psychological support of educational and professional activities $[4,7]$.

Multi-level personal questionnaire (MPQ) "Adaptability» consists of 165 questions and has 4 structural levels, that allow you to obtain information of varying volume and character [7, 9].

-Scales of the 1 st level are independent and correspond to the basic SMIL scales (MMPI), allow to obtain typological characteristics of the personality, to determine the accentuating of the character.

-Level 2 scales correspond to the scales of the DAD questionnaire («Disadaptive disorders»), designed to identify disadaptation disorders, primarily asthenic and psychotic reactions and conditions.

-Level 3 scales: behavioral regulation (BR), communicative potential (CP) and moral 
normativity (MN).

-Scale of the 4-th level - personal adaptive potential (PAP).

The theoretical basis of the test is the idea of adaptation as a constant process of active adaptation of the individual to the conditions of the social environment affecting all levels of human functioning. Characterization of the personal potential of adaptation can be obtained by evaluating behavioral regulation, communicative abilities and the level of moral normality.

Behavioral regulation (BR) is a concept that characterizes a person's ability to regulate his interaction with the environment activities. The main elements of behavioral regulation are: self-esteem, the level of neuropsychological stability, and the presence of social approval (social support) from the surrounding people. All the allocated structural elements are not the first principle of regulation of behavior.

Communicative qualities (communicative potential, (CP) are determined by the presence of the experience and communication needs, as well as the level of conflict.

Moral normativity (MN) provides the ability to adequately perceive by individual proposed for him/her a certain social role. In this test, questions that characterize the level of moral normality of an individual are reflected on the two main components of the process of socialization: perception of moral and ethical norms of behavior and attitude to the requirements of the immediate social environment.

The method «The Study the motives of students' learning activity» was proposed by A.A. Rean and V.A. Yakunin. For each student a qualitative analysis of the leading motives of educational activity is performed. Throughout the sample (group), the frequency of choosing a particular motive is determined [7].

Results of the study. According to the results of the MPQ «Adaptability», female first-year students showed higher rates for all structural levels (Table 1). Also, the personal potential of adaptation was higher among female students, namely: the indicators of behavioral regulation (in the stens) among the female students were $3,50 \pm 0,24$, for boys the same figure was $3,36 \pm 0,32$. For girls, the indicators of communicative potential and moral normativity were 4,36 $\pm 0,23$

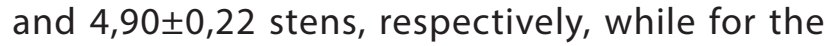

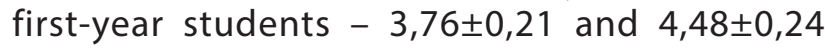
stens. At the same time, the indicator of disadaptation disorders was also higher among female first-year students $(4,90 \pm 0,22$ versus $4,48 \pm 0,24$ for male students). Perhaps, this is due to the fact that girls have more conscious and responsible attitude preparation for classes; they are more attached to their parents and suffer painful separation from them. In addition, girls tend to have a higher sensitivity and a greater level of empathy; that can contribute to the development of emotional burnout syndrome in medical students at the stage of training, and this, in this case, we identify as disadaptation disorders.

Asthenic and psychotic reactions were also higher in female students $(5,48 \pm 0,25$ and $4,31 \pm 0,20$ respectively) compared with male students (asthenic reactions $-5,36 \pm 0,35$ stens, psychotic reaction of $4,12 \pm 0,24$ stens). Female students often complained of increased fatigue, forgetfulness, unstable attention, vegetative disorders. Vegetative disorders were often dominant in the asthenic syndrome view and were manifested by headaches, a feeling of heaviness in the head, abnormalities of the cardiovascular system of varying severity increased sweating, dyspeptic disorders, disturbances and/or inversions of sleep. Along with fatigue and unproductive intellectual activity our respondents were shown impaired mental balance, irritability, irascibility, cantankerousness, fragmentary psychotic components.

The personal adaptive potential was also higher for female respondents $(2,52 \pm 0,21$ in girls and 2,04 $\pm 0,22$ in boys). Some researchers identify the adaptive potential of an individual as an integrative characteristic of mental health. Mental adaptability here is determined by a number of components - the overall level of mental development, personality characteristics and the system of relationships, the nature and the content of psychological problems, and the position of the individual in relation to them. According to A.G. Maklakov [4], personal adaptive potential represents interrelated psychological features of the individual, determining the effectiveness of adaptation and the likelihood of professional health maintaining. In the condition of the constant risk of the emotional burnout syndrome development the medical profession is already beginning at the stage of training in the university, - the last statement acquires special significance. The personal adaptive potential includes the level of neuropsychological resistance, self-evaluation, the level of conflict-specific features, moral qualities, orientation to behavioral existing norms. 
Table of students' adaptive characteristics (in stens, $\mathbf{M} \pm \mathbf{m}$ )

\begin{tabular}{|c|c|c|c|c|c|c|c|}
\hline Students & PAP & BR & CP & MN & DD & AR & PR \\
\cline { 1 - 5 } girls $(n=42)$ & $2,52 \pm 0,21$ & $3,50 \pm 0,24$ & $4,36 \pm 0,23$ & $4,90 \pm 0,22$ & $4,90 \pm 0,22$ & $5,48 \pm 0,25$ & $4,31 \pm 0,20$ \\
\hline guys $(n=25)$ & $2,04 \pm 0,22$ & $3,36 \pm 0,32$ & $3,76 \pm 0,21$ & $4,48 \pm 0,24$ & $4,48 \pm 0,24$ & $5,36 \pm 0,35$ & $4,12 \pm 0,24$ \\
\hline
\end{tabular}

Legend: personal adaptive potential - PAP; behavioral regulation - BR; communicative potential - $C P$; moral normativity - MN; disadaptative disorders - DD; asthenic reactions - AR; psychotic reactions - PR.

Study results of the academic activity motives of the first-year medical students are presented in Table 2. As it could be seen from Table 2, all interviewed female students (100\%) and only $87 \%$ of male students wanted to «become a high-class specialist», that we can interpret as long-term dreams and fantasies. After all, in order to realize this motive, it is necessary "to study successfully and take exams for 5 and $4 »$, but only $51 \%$ of girls and $58 \%$ of guys are motivated for this action. $31 \%$ of girls and $42 \%$ of boys «wanted to be constantly ready for the next classes»; $56 \%$ of girls and $74 \%$ of boys expressed the desire to "successfully continue their education on subsequent courses», what we could explain by the prevalence of the asthenic symptom complex among female students identified by the MPQ «Adaptability». At the same time, girls were more motivated to "acquire deep and strong knowledge» (95\% of girls and $87 \%$ of guys), and "to ensure the success of future professional activity» (79\% of girls and $74 \%$ of guys). Most of male students have expressed the desire "to get intellectual satisfaction» (guys - 74\%, girls - 67\%). Such motives as «to avoid conviction and punishment for poor study», "to be an example for another students», «to keep up with another students», «to get approval from parents and others» were chosen by less than half of the respondents of both genders, that was regarded by us as a conflict of motives and immaturity of the psychological essence of intentions inherent in adolescence.

\section{Indicators of study motives among medical students (\%)}

Table 2.

\begin{tabular}{|c|l|c|c|}
\hline \multirow{2}{*}{ № } & \multicolumn{1}{|c|}{ Motives for learning activities } & \multicolumn{2}{c|}{ Students } \\
\cline { 4 - 5 } & & girls (\%) & guys (\%) \\
\hline 1 & Become a highly qualified specialist & 100 & 87 \\
\hline 2 & Get a diploma & 69 & 70 \\
\hline 3 & Successfully continue training in subsequent courses & 56 & 74 \\
\hline 4 & Successfully study, pass exams for «5» and «4» & 51 & 58 \\
\hline 5 & Always receive a scholarship & 15 & 13 \\
\hline 6 & Acquire deep and solid knowledge & 95 & 87 \\
\hline 7 & Be constantly ready for the next class & 31 & 42 \\
\hline 8 & Do not suspend the study of subjects of the training cycle & 67 & 68 \\
\hline 9 & Keep up with another students & 28 & 32 \\
\hline 10 & Ensure the success of future professional activities & 79 & 74 \\
\hline 11 & Perform pedagogical requirements & 46 & 45 \\
\hline 12 & Achieve the respect of teachers & 64 & 61 \\
\hline 13 & Be an example for another students & 18 & 32 \\
\hline 14 & To achieve the approval of parents and others & 36 & 32 \\
\hline 15 & Avoid conviction and punishment for pure study & 8 & 13 \\
\hline 16 & Get intellectual satisfaction & 67 & 74 \\
\hline
\end{tabular}


Comparing the data of the two questionnaires, we have found the following features. Both male and female respondents of our study were showing an expressed asthenic symptom, which, however, was more pronounced among female students. Also in both subgroups of students, decreased personal adaptive potential was found, and among guys it was, albeit slightly, but lower than among girls of the same age. These results confirm the hypothesis that learning at university is a stress for the student, violating his/her adaptation processes. Guys among all the proposed motivational incentives were more likely than girls choosing the statement "get a diploma», "successfully continue study at subsequent courses», «set an example for another students» and "get intellectual satisfaction». Most girls among the kinds of motivations chose «to become a highly qualified specialist», "to acquire deep and strong knowledge», "to ensure the success of future professional activity». Thus, the obtained data indicate mainly external motivation among male students and predominantly internal motivation among female students. The motives of the girls' choosing were mainly cognitive and motives of professional achievements, while the guys had social motives and motives for personal prestige. From literary sources it is known that the features of motivation revealed in our work are the most significant for the academic achievement of students during process of university education [5].

Conclusions. Stressful factors that affect the first year medical students have negative impact on adaptive abilities, worsening the overall psychoemotional state. Studying the motives of educational activity revealed good potential for the first-year students of the first semester of training, therefore it can be concluded that a short time period of exposure to stress factors still allows students to use their own internal resources for self-healing without deprivation of motivational component of the learning.

As it was mentioned above, when forming a professional, educational motivation, cognitive processes (for example, memory processes) are actualized and positive emotional experiences arise. Therefore, we can conclude that the formation of adequate motivation for learning can help the first year students to cope with the disadaptation of the first year of training, and also to prevent the early onset of the formation of neurotic spectrum disorders, including the emotional burnout syndrome. The obtained data should be considered when developing a psychocorrectional complex for management of existing psychoemotional disorders among the first year medical students.

\section{Literature.}

1. Вовк В. И. Значение психодиагностики личностных особенностей для разработки психокоррекционных мероприятий / В. И. Вовк // Медицинская психология.-- 2014.-- Т. 9, № 4 (36).-- С. 66-70.

2. Данилова Н. Н. Физиология высшей нервной деятельности / Н. Н. Данилова, А. Л. Крылова.-- Ростов-на-Дону: «Феникс», 2005.-478 c.

3. Клепач Ю. В. Особенности учебно-профессиональной мотивации и тревожности у студентов-психологов и студентов медицинского колледжа / Ю. В. Клепач, О. О. Разуваева // Известия ВГПУ.-- 2015.-- № 4 (269).-- С. 140-143.

4. Маклаков А. Г. Личностный адаптационный потенциал: его мобилизация и прогнозирование в экстремальных условиях / A. Г. Маклаков // Психологический журнал.-2001.-- T. 22, № 1.-- С. 16-24.

5. Мещерякова И. Н. Особенности мотивации учебной деятельности студентов-психологов различных курсов / И. Н. Мещерякова // Известия ВГПУ.-- 2015.-- № 4 (269).-- С. 137-139.
6. Пономарев В. И. Развитие психосоматических расстройств у студентов младших курсов / В. И. Пономарев, В. И. Вовк, О. Н. Каплоух // Материалы VII международной конференции: «Современные концепции научных исследований» (Россия, г. Москва, 30-31 октября 2014 г.).-- С. 34-35.

7. Бодалев А. А. Рабочая книга практического психолога: Технология эффективной профессиональной деятельности (пособие для специалистов, работающих с персоналом) / А. А. Бодалев, А. А. Деркач, Л. Г. Лаптев.-- М.: «Красная площадь», 1996.-- 400 с.

8. Соловьёв В. Н. Влияние адаптации и мотивации учебной деятельности на успеваемость студентов / В. Н. Соловьёв // Фундаментальные исследования.-- 2004.-- № 5.-- С. 81-83.

9. Сукачева О. Н. Формирование адаптивных способностей у студентов-медиков 1 курса / О. Н. Сукачева, Д. Н. Волошина // Проблеми сучасної освіти : збірник науково-методичних праць.-- Вип. 8. У 2 ч.: Ч. 1.-- Х.: ХНУ імені В. Н. Каразіна, 2017-- С. 114-118. 